\title{
The Islamist Politics in the Era of Neoliberal Globalization The Case of Jamaat-E-Islami Pakistan
}

\author{
Husnul Amin \\ Post-doc Research Fellow, Berlin Graduate School Muslim Cultures and Societies \\ Department of Politics, Faculty of Social Sciences, International Islamic University Islamabad \\ Email: husnulamin@hotmail.com
}

\section{Doi:10.5901/mjss.2014.v5n15p507}

\section{Abstract}

The essentialist theoretical approaches assume Islamic movements, if got access to state power, will lead their respective societies to a kind of totalitarian state, a condition resulting into complete destruction of the existing social, political and cultural traditions and replacing them with new political institutions. Such an imagination of the Islamic movements is further ignited by the Islamic movements' self-portrayal as the harbingers of "total" change and "radical revolution" that is normally termed as Islamic revolution. In a political sociology setting, this research focuses on an empirical example of one of the oldest Islamic movements in the Mulsim world, the Jamaat-e-Islami Pakistan-a religious political party founded in 1941 by Sayed A. A Mawdudi. Using multiple sources of information, this paper drags the discussion beyond essentialist assumptions of Stone Age and Islamists' claims of bringing about radical revolution. It does so by focusing on news content data collected from two major Pakistani newspapers published in Urdu language as well as the content analysis of 1997 electoral manifesto of the Jamaat-eIslami. The data set consists of time period 1988-2006. However, the post 2006 developments are also added to the analysis. This research makes contribution to the existing body of academic scholarship on the subject both methodologically and substantially. Whereas most of the hitherto conducted researches deal either with the history, ideology, electoral politics or Jamaat-e-Islami's connection with global jihad. This research departs from the conventional treatment both methodologically and theoretically. Using simple descriptive statistics, this paper makes a humble attempt to measure the diverse responses of the Jamaat leaders to issues of national and global importance. It shows that how statements of its leaders and the manifesto content reflect on variety of issues that might not fit into the theoretical assumptions, stereotypical categories and textual readings by essentialists and reductionists. By bringing political practice in the analysis, the data confirms that unlike Islamophobic provocations, the mainstream political Islamists are not dragging Pakistan into a "Stone Age". Likewise, the fears of a radical revolution, if the Islamists take control of the state, have no firm grounds.

\section{Introduction}

The concepts of political Islam and Islamism are employed here as a phenomenon inspired by S.A.A. Mawdudi's (19031979) ideology of Islamic revival through the establishment of an Islamic state. This specification narrows the focus in the given context of the study and does not assume that prevalence of Islamism or Mawdudi's influence is confined only to Pakistan. Another important distinction is between institutional and militant Islamism. In contrast to the latter, the former is a category that primarily opts for democratic means. Conceptually, it will be difficult to disentangle the Jamaat-e-Islami's (henceforth $\mathrm{Jl}$ and the Jamaat will be used interchangeably) tacit and latent connections, moral approvals for and sympathies with various militant organizations across the Muslim world. However, within the boundaries of Pakistan, the $\mathrm{JI}$ has largely employed social, political and electoral means in its political struggle.

In his study Islamism and Islam, renowned German scholar Bassam Tibi (2012) draws a clear though simplistic distinction between "Islam" and "Islamism." the former as religion and the latter as totalitarian ideology which is supposed to establish a state based on sharia. According to Tibi, "it is a great mistake to view Islamism as liberation theology characterized by an 'attempt to repair."' On the contrary, Tibi argues, Islamism proffers an "agenda of cultural-totalitarian purification" and as there can be no "democratic totalitarianism," there cannot be a "democratic Islamism" (ibid, p.186). After drawing such sharp distinction, Tibi does not find himself in a position to trust Islamists that they will forego violence and will wholeheartedly accept a pluralistic order within a democratic system. In his bold assertion based on Arendt's concept of "totalitarianism," Tibi ascribes totalitarianism to Islamism (though not Islam). For this we need to unpack Arendt's conceptualization of totalitarianism. In an explanatory article on Hannah Arendt's theory of totalitarianism, Anthony Court unpacks her key passage on the subject as:

.... Arendt's conception of society reduced to 'One Man' or a single, undifferentiated Mankind as a condition of a 
'perfect totalitarian government'. We may note here that totalitarianism thus conceived constitutes the very antithesis of the political in Arendt's sense of men acting and speaking together in a public realm of politics. Secondly, Arendt contends that only in such a perfect totalitarian system would terror, which she views as the 'essence' of totalitarianism, suffice to sustain totalitarian rule. Hence, in all imperfect totalitarian dictatorships, terror in its dual function as the 'essence of government and principle, not of action, but of motion' .... is an insufficient condition of totalitarian rule. For, insofar as totalitarianism has not completely eliminated all forms of spontaneous human action, freedom, or the inherent human capacity to 'make a new beginning', exists as an ever-present potential within society .... Totalitarian movements must therefore strive to eliminate this capacity for political action, and any form of spontaneous human relations. (Court, 2012)

Tibi is not alone in his essentialist leanings and reification of Islamic essence that gives impetus to representation of Muslims as distinct category. This and such other essentialist readings of Islam reduces complex social processes to certain unchanging traits, inherent fixity, thus making it incompatible with modernity. The inability of Muslims to be congruent with requirements of modern age testify to the fact that something has gone "wrong with Islam" (Lewis, 2002). The Orientalists, the conventional authorities on Islam, "have been accused of being essentialist and insensitive to the change, negotiation, development, and diversity that characterizes lived Islam" (Anjum, 2007). This approach to understanding Islam and Muslim societies is weaved in the modernization theory of scholars such as Bernard Lewis, Bassam Tibi, Sivan and Daniel Pipes. Another key feature of the essentialist scholars is their attempt to reduce complex social, historical and cultural processes into oppositional dichotomies: that is, traditional versus modern, religious versus secular, old versus new. However, in Esposito's account, few Islamic movements and activists in the Muslim world specifically the Middle East will fit in this stereotypical account. "Many of the leaders of Islamic organizations are graduates of major universities from faculties of medicine, science, and engineering" (for further details see, Kramer, 2003; Ahmad, 1991). Lewis's accusation of Islamic fundamentalists' abrogation to all "imported norms" is also not supported by the ground realities. On the contrary, "[t]he widespread use of radio, television, audio and videocassettes, computers and fax machines, has made for a more effective communication of Islam nationally and transnationally" (Esposito, 1999). The two oldest Islamic movements (Muslim Brotherhood in Egypt founded in 1928 and the JI in Pakistan founded in 1941) exemplify "new styles of Islamic organization", and they never called for "return to pre-modern conditions" (Esposito \& Voll, 1996).

\section{Neoliberal Globalization and New Opportunity Spaces}

Globalization in this paper is defined as "time-space compression" in global economic, cultural and socio-political relations. Neoliberalism refers to both economic theory and a policy prescription. As theoretical construct, neoliberalism promotes a free market economy with less governmental control and regulation. The neoliberal ideology views that less regulation and more freedom guarantees economic efficiency, growth and distributional justice (see Kotz, 2002).

There is considerable growth in academic research on Islamic political movements, mainly focusing on their grand ideologies, organizational structures, electoral politics, and welfare networks and their multifarious responses to the opportunities offered by globalization. Significant academic attention is paid to the attitude of Islamic movements to globalization and cross cultural interactions (some studies refer to Sayyid Qutb (d. 1966) as the main ideologue of antiWestern ideational framework in whose' critique modernity is considered as jahiliyya, see for instance, Euben, 1999). Like several other Muslim societies, in Pakistan too, in the 1980s, the process of openness, de-regulation, privatization and liberalization paved the way for multiple economic and social forces to enter into the realm of market, media and politics and thus to pursue multiple goals ranging from earning economic profits to enhancing social and political influence. The privatization and de-regulation drive set in initially in the economic sector had to have far reaching implications in other sectors of economy and society as well. Due to inflow of resources from multiple sources (aid, war-time assistance, remittances etc.) during 80 s, 90 s and then after $9 / 11$, has given birth to and then consolidation of a sizable middle class in Pakistani society. According to Nayab (2011) the middle class has expanded to 35 percent which is about 61 million of Pakistan's current population. The number has increased from 34 million to over 61 million. Geographically, the provinces of Punjab and Sindh have more than 36 percent middle class households, while Khyber Pakhtunkhwa (KPK) having 32 percent and Baluchistan 28 percent. Nayab's weighted composite index for measuring middle classes in Pakistan is a "combination of relative and absolute approaches." For example, the composite index consists of educational index, income index, housing index, lifestyle index, occupation index.

In the context of Pakistan, neoliberal globalization refers to a specific era, the last three decades, in which the global multifaceted relations have intensified. With the dawn of neoliberal era in the 1980s and continuing to date, the economy, politics, market and media sectors in Pakistan have witnessed tremendous change and transformation. 
Structure of the economy has largely changed from agriculture and rural to services and industrial. In the realm of market, politics and new electronic media have generated new opportunity spaces for engagement of diverse social forces. In 1988, Pakistan initiated the neoliberal economic doctrine on the advice of International Monetary Fund (IMF). In the 1990s, it adopted the Structural Adjustment Programs and took on the policy of privatization, liberalization and deregulation. The loan facility availed under the arrangements was attached to numerous terms and conditions such as "removal of price control, ended subsidies, eliminate tariff protection, privatize government enterprises, forced deregulation to minimize the role of the state in social sector including environmental standards" (for a detailed account of structural adjustment programs and neoliberal policy, see Zaidi, 2005). Though privatization was not new but it gained momentum during this period. This study is not concerned with the ill-effects of this process neither how it impacted the poor sections of society.

One important growth rate could be recorded in the private television and radio channels. As opposed to a state run TV Channel (PTV) and public sector radio stations, Pakistan is having more than 1000 radio private channels as well as some 100 private TV channels. The number of internet users is around 33 million with a proliferation rate of less than Egypt, Iran and Tunisia. According to a report the total number of Facebook users reaching about 8.5 million with $70 \%$ male and 30\% female users. Likewise, the education sector has also attracted private investments and the number of privet schools, colleges and universities has increased tremendously. One evidence suggests that only in 1999-2000 and 2007-2008, number of private schools in Pakistan increased by 69 percent as compared to 8 percent increase of government schools (ISPS study 2010). The number of students enrolled in private schools rose to 12 million in 2007-08 which was 34 percent of the total enrolment.

The $\mathrm{Jl}$ like other Islamic movements do not operate in a vacuum and is bound to work within shrinking and expanding opportunity spaces. Coined by Yavuz (2003), the concept of opportunity spaces seems relevant here. It refers to "fora of social interactions that create new possibilities for augmenting networks of shared meaning and associational life" (Yavuz, 2003). According to Yavuz, it includes "civic and political forums, electronic and print media, and cyberspace and the market' (ibid, p.24). The expansion of opportunity spaces (democratisation, market and the new private media) in Pakistan that created new opportunities for the Islamists. In this paper, by opportunity spaces, I imply two things: first, global opportunities, which arose due to shrinking of state control and regulation, and which enabled transnational social movements to diffuse institutionally; second, global networks and resources, which upkeep social movements both ideationally and materially.

This research aims to look beyond stereotypical categories of Stone Age and radical transformation of state and society and concentrates on the study of mainstream Islamist party the Jamaat-e-Islami Pakistan and the ways it respond to opportunities created by the wave of globalization in the realm of market, media and politics. After a brief overview of the theoretical approaches and a discussion on the opportunity spaces created by the recent neoliberal globalization, the remainder of the paper is organized into three sections. Section one provides a brief historical account of the Jamaat-eIslami Pakistan, lays out research questions and the research methodology. The last section provides a descriptive analysis of the data and a brief conclusion warps up the discussion.

\section{The JI and its Politics: An Historical Account}

The $\mathrm{JI}$ represents one of the mainstream Islamic political parties in Pakistan. It holds the distinction of being founded and led for around three decades (1941-1972) by the main Islamist ideologue-S.A.A. Mawdudi. The Jl's ideological literature, mostly authored by Mawdudi, was translated into more than 28 languages, and in this way, it inspired and attracted individuals across the globe towards political vision of Islam. The Jamaat has been through multiple experiences. It remained in opposition and suffered from state repression in the 1960s and 1970s; co-opted with the military regime in power and benefited from opportunities in the 1980s; actively participated in the political process in the 1990s; participated in elections and exercised power in 2002-2007 and again as coalition party in the KPK provincial government. Although, it failed in realizing its political dreams, the $\mathrm{Jl}$ was quite successful in achieving an Islamic constitution for Pakistan (Nasr, 1994).

The $\mathrm{Jl}$ in Pakistan and its founder Mawdudi are well known to the Western academic world. Mawdudi's revivalist thought spurred Islamic political revivalist trends not only in South Asia but also in the wider Muslim world. At least five JI groups in South Asia (Pakistan, India, Bangladesh, Sri Lanka and both sides of Kashmir) subscribe wholeheartedly to Mawdudi's worldview of Islamic revival. His enormous influence on renowned ideologues-activists, Egyptian Sayyid Qutb, Iranian Khomeini, Tunisian Ghanoushi, and worldwide Islamic social forces and activists appears in studies on Muslim societies. Mawdudi's articulations on Islamic beliefs and practices, and his blueprint for socio-economic order and educational system, as articulated in his major works. In Pakistan, his vision of an Islamic state became a popular idiom 
and mainstream political discourse. The Jamaat emerged as the most well-disciplined and organized political party in Pakistan, which also inspired numerous sister professional organizations and trade unions among communities of teachers, doctors, engineers, lawyers and laborers.

A number of scholarly accounts have shown that the Jamaat has changed or is changing. Some accounts identified the "end of ideology" and the beginning of pragmatic politics at a very early stage in the history of the Jamaat (on the Jamaat transformation and change, see for example, Ahmad, 2009; Azmi, 2002; Moten, 2002; Nasr, 1994).

\section{Research Questions and Methodology}

This paper lays out one main argument. In the era of neoliberal globalization, as the opportunity spaces in the realm of politics, economy, media and social sector expanded, the JI has diversified its responses as well as activities. The Jl's response diversification shows that it has slowly moved away from its main project of establishing an authoritarian Islamic state to an idea that accepts pluralism. Although due to numerous inner dynamics (party's immediate past, lack of charismatic leadership, intellectual deficit, Mawudid's ideological burden, failure of the $\mathrm{Jl}$ in negotiating its normative framework) the Jl largely failed making it a popular party winning considerable public will; yet, evidence coming from multiple sources strongly suggests steadily growing diversification and accommodation. The data presented in this paper is more symptomatic than an indicator of this change. This paper problematizes the Eurocentric assumption about the linearity, homogeneity and continuity of Islamic movements. The empirical evidence provided in this study reflects the diversity of Jl's responses both across issues and across time. Using multiple sources of information, the politics of the JI indicates that its response has not been homogenous rather has been oscillating between rejection, negotiation and accommodation. Why did the $\mathrm{JI}$ reject, then negotiate and later even accommodate globalization and its opportunities? I argue that the Jl's response has been contingent up opportunity spaces as discussed above. The main proposition to be tested in this paper is: the more opportunity spaces are opened up for the $\mathrm{Jl}$ as a result of neoliberal globalization, the more it negotiates its hard line anti-globalization stance, softens its normative framework and opens up to cross-cultural interactions.

The information generated from the news content and manifesto data will answer a set of specific descriptive questions such as: what are the current trends and issues in the Jamaat politics in Pakistan; what issues are more significant and what are less significant; what are the major contours of Islamist politics understood through these issues; what is the Jamaat position on major national issues in particular developmental issues, and how can a description of these trends and concerns enrich our understanding of the Jamaat politics in Pakistan?

Manifestoes of Islamic political parties reflect their ideology, philosophy and programme for change in Pakistan. To what extent does the Jamaat manifesto reflect its actual intentions, how far does the political practice of the Jamaat correspond to the ambitious goals identified in it and how many people actually read them? Asking these and other questions does not prohibit us from exploring and understanding the content of the manifestoes and measuring policy position. Although, manifestoes express wishful intentions of the political actors to change the destiny of the nation, they are "authoritative statements" ratified and owned by party elites and activists alike. Reading the content of manifestoes can serve numerous purposes: identifying change in party ideology over time; comparison across party ideology and policy positions; determining how much weight parties attached to different policy issues, and if the party in question grabs power, to what extent, it sticks to or deviates from its own promises made in the election platforms.

Using Comparative Manifesto Project's (CMP) coding scheme (Budge, 2001; Volken, 2005; Laver, et al 2003), the Jamaat position on various political, social and economic issues is measured. The aim is to obtain an overview of the Jl's imagined Islamic state and the contours of its socio-political activism in Pakistan. For the content analysis, this section employs two main sources: the JI election manifesto (Ashar, 2004) of 1997 and the news content of two Urdu dailies published in Pakistan -Daily Jang (Rawalpindi) and Daily Nawa-e-Waqt (Islamabad).

As a family-owned newspaper, the Daily Jang was first published in 1941 in New Delhi and was then moved to Karachi after partition of Colonial India in 1947. The newspaper has persistently retained its wider circulation throughout the geographical locations of Pakistan. Akhtar mentions lack of ideological commitment of Jang "except supporting the party in power and then drifting away to the other group" (Akhtar, 2000). Apart from publishing an English Daily (The News), a family magazine, currently, the most popular private TV channel Geo is also owned by the Jang Group. In contrast, the Daily Nawa-e-Waqt "speaks for the nation's conservative Muslim constituency" (ibid, XXVI). Both Jang and Nawa-e-Waqt have consistently accommodated new technological tools and professional ingenuities. Both have respectively an "estimated circulation of 500,000 and 400,000 copies per day" (ibid, pp. XXVI-XXVII).

The news content spans from 1988 to 2006, the period of utmost significance in Pakistan's political and economic history. For instance, democracy returned to Pakistan after the sudden death of Zia-ul-Haq in an air crash in 1988. The 
struggle for Kashmir independence underwent a major shift from ballot to bullet; with the disintegration of communist Russia and rise and fall of Taliban (1995-2001) in Afghanistan. In addition, the era of neo-liberal policies and structural adjustment programmes in the 1990s, and an alliance of all major religious parties called Muttaheda Majlise Amal (MMA) marked an historic victory in the 2002 general elections enabling MMA to form its own government in the KPK province and join a coalition government in Baluchistan province.

\section{Quantification and Classification}

Following Comparative Manifesto Project (CMP), the coding unit in the Jamaat manifesto and news statement is the quasi-sentence defined as "an argument." An argument is the "verbal expression of one political idea or issue." The basic unit is the 'sentence' but it can be decomposed into different arguments, if the structure of the sentence allows. For example, if the Jamaat manifesto claims that "we will eradicate poverty and curb inflation", it is one sentence with two arguments-to alleviate poverty, and curb inflation. Here we can draw a rule of thumb: complex statements and texts are decomposed into quasi-sentences for arguments as and when the sense changes, where a quasi-sentence is a "set of words, containing one and only one, political idea (Volkens, 2005).

The following is the classification scheme (see table 1), developed by CMP. I have modified it for the Jamaat in Pakistan and grouped the statements into eight major policy areas called policy domains, from D1 to D8. In the original CMP scheme, there are seven policy domains (i.e. D1-D7). However, to capture the Jamaat discourse on Islamic Sharia and Islamisation of economy and society, I have added a domain for Islamic ideology (D8). Each domain is further divided into sub-domains or issues/themes. The positive $(+)$ sign means that some positive statement or reference is made about the issue in question and negative sign (-) means a negative reference.

As mentioned above, I have two sources of data-manifesto and the news content. The manifesto content is coded under 8 domains: External Relations, Freedom and Democracy, Political System, Economy, Welfare and Quality of Life, Fabric of Society, Social Groups and Islamic Ideology. However, in light of news content, I further modified my own scheme used for manifesto content. For example, D4 (Economy) is treated as an aggregate category, where subdomains merge. Likewise, in D3, political activism represents news content; in D2, freedom and democracy for new content absorbs all sub-domains; in D5, social activism is an additional sub-domain that captures the Jamaat welfare activities specifically at the time of relief and emergencies, and finally, in D6, ethno-politics is an additional sub-domain to capture the Jamaat mostly negative mention of the regional and ethnic politics in Pakistan.

The coding of news and manifesto content was done following a careful and systematic procedure. Using a modified CMP scheme, three research assistants were hired, trained and engaged in collecting/writing down all news statements issued by the Jamaat local, provincial and national leadership, which appeared in these newspapers-Jang or Nawa-e-Waqt. Only the news pages were consulted and the editorial content/columns/op-ed. were left out. The research assistants would pick a file of the Daily Jang, leaf through all the news pages, locate news statements issued by the Jamaat leaders and will note them down into a note book along with name, date and place. In selection of newspapers, a rule of thumb was defined by the author: that is, first, the Daily Jang Rawalpindi was searched in the shelves; if not available, then Daily Jang Lahore or Karachi, and that if not available, then the Daily Nawa-e-Waqt was consulted. In about a month time, all newspaper files spanning 1988-2006 were thoroughly searched for the Jamaat leaders' statements. To check for the reliability of the research assistants' work, the author hired two more research assistants who randomly verified the news statements recorded and looked for the missing files. In a total duration of 45 days, the author had a compilation of huge text in the form of news statements issued by the Jamaat leaders. Using modified CMP, I developed a coding scheme and assigned similar numerical codes to similar statements. Following this procedure, I had a database for the news content comprising of 2726 observations, for the Jamaat. These observations were further categorized along the 8 main domains (see table 1).

Table 1: Domains and Sub-Domains

\begin{tabular}{|l|l|l|}
\hline \multicolumn{1}{|c|}{ Domain } & \multicolumn{1}{c|}{ Sub-Domains } \\
\hline D1 & External Relations & Anti-Imperialism +; Military Defence +; Peace +; Internationalism +; Pan-Islamism +; Foreign Policy \\
\hline D2 & Freedom and Democracy & Freedom and Human Rights +; Freedom and Human Rights -; Democracy +; Constitutionalism + \\
\hline D3 $\begin{array}{l}\text { Political System/ } \\
\text { Political Activism }\end{array}$ & $\begin{array}{l}\text { Governmental and Administrative Efficiency +; Governmental and Administrative Efficiency -; } \\
\text { Corruption and Accountability; Decentralization and Provincial Autonomy +; Centralization +; }\end{array}$ \\
\hline D4 & Economy & $\begin{array}{l}\text { Free Enterprise +; Incentives +; Market Regulation +; Protection +; Economic Planning +; General } \\
\text { Economic Goals +; Technology and Infrastructure +; Nationalization +; Privatization + }\end{array}$ \\
\hline
\end{tabular}




\begin{tabular}{|c|c|c|}
\hline D5 & $\begin{array}{l}\text { Welfare and Quality of } \\
\text { Life/Social Activism }\end{array}$ & $\begin{array}{l}\text { Social Justice +; Culture +; Welfare State Expansion +; Education Expansion +; Environmental } \\
\text { Protection + }\end{array}$ \\
\hline D6 & $\begin{array}{l}\text { Fabric of Society/ } \\
\text { Ethno-politics - }\end{array}$ & Social Harmony +; Law and Order +; Anti-Feudalism and Land Reform +; Anti-Capitalism + \\
\hline D & Social Groups & $\begin{array}{l}\text { Labor Groups +; Farmers +; Under-privileged and Minority Groups +; Professional Groups +; Gender } \\
+; \text { Youth +; Other Social Groups + }\end{array}$ \\
\hline & $\begin{array}{l}\text { Islamic Ideology/Jihad } \\
\text { Activism }\end{array}$ & Islamic Sharia +; Islamic Economy +; Islamic Morality +; Islamization (general) \\
\hline
\end{tabular}

Source: Modified from Volkens (2005)

Table 2: All Domains: Manifesto and News Content Data (1988-2006)

\begin{tabular}{|c|c|c|c|c|}
\hline \multirow{2}{*}{ Domain } & \multicolumn{2}{|c|}{ Manifesto } & \multicolumn{2}{|c|}{ News Content } \\
\hline & Count & in $\%$ & Count & in $\%$ \\
\hline D1: External Relations & 56 & 9.0 & 597 & 21.9 \\
\hline D2: Freedom and Democracy & 39 & 6.2 & 136 & 5.0 \\
\hline D3: Political System/Political Activism* & 100 & 16.0 & 1088 & 39.9 \\
\hline D4: Economy & 109 & 17.4 & 111 & 4.1 \\
\hline D5: Welfare and Quality of Life/Social Activism* & 110 & 17.6 & 242 & 8.9 \\
\hline D6: Fabric of Society/Ethno-politics* & 60 & 9.6 & 135 & 5.0 \\
\hline D7: Social Groups & 113 & 18.1 & 125 & 4.6 \\
\hline D8: Islamic Ideology & 38 & 6.1 & 292 & 10.7 \\
\hline Total & 625 & 100.0 & 2726 & 100.0 \\
\hline
\end{tabular}

Source: Author's own database

A similar coding method was applied to the quantification of the Jamaat manifesto (issued at 1997 elections). The author carefully read and interpreted the manifesto content and assigned relevant codes. At the end, a total number of 625 observations were obtained that were further grouped into 8 categories, shown in table 2.

Unfortunately, Islamist parties do not update their manifestoes regularly and normally reprint older versions before elections, which make the comparison across time difficult. The Jamaat has updated its manifesto but with no substantial departure from the previous versions. The news data enables us to compare and contrast the issues across time as well. The limitation is that we deal only with a time span from 1988 to 2006. The eight main policy domains and sub-domains are in given in table 1.

\section{Data Analysis}

Table 2 presents an aggregated picture of the main domains. In the Jamaat manifesto, social groups received more attention (18.08 per cent) than the rest. Four domains (D3, D4, D5 and D7) capture around 70 per cent of the total. The share of Islamic ideology is lower than expected for an Islamist organization like the Jamaat. The news content in the same table show political activism (39.91 per cent) followed by external relations (21.90 per cent) and Islamic ideology (10.71 per cent) claim the majority share. However, economy and welfare and quality of life receive 4.07 per cent and 8.88 per cent respectively. The table portrays diversity and not homogeneity in the Islamist political and public discourse.

Tables 3 to 10 show a breakdown of the data presented in table 2. It is clear from table 2 that the Jamaat has paid disproportionally more attention, in the news content data, to issues around global politics, Kashmir and Afghanistan. Whereas, pan-Islamism dominates the manifesto content, Kashmir and Afghanistan outshines in the news content. Military and defense are salient, global peace and internationalism appears less visible in the data. As manifest from table 2, and further elaborated in table 4, freedoms, human rights and democracy do not fill the central content of Islamist political discourse. Apart from the figure, if we look at the content of the human rights issues, more focus goes to the violation of human rights in Kashmir and other conflict zones than abuses of human rights within the country. In table 5, governmental and administrative efficiency received more attention (57 per cent) followed by corruption and accountability (32 per cent), which are potentially more populist in nature; however, decentralization and provincial 
autonomy, which are more pressing in the Pakistani context are not central to the Islamists debates. As evident from table 2 and 6 economy slips as a main component in the activism of the Jamaat. In the news content, a relative share of 4.1 per cent is far less than in the manifesto content, which is 17.4 per cent. Mawdudi's text, the Jamaat manifesto and the news data nearly confirm that their proposed Islamic economy would be a mixed capitalist economy with a vibrant free enterprise and less state control.

\begin{tabular}{|l|l|l|l|l|}
\hline \multicolumn{5}{|c|}{ Table 3: Sub-Domain: External Relations } \\
\hline & Manifesto & \multicolumn{2}{l|}{ News Content } \\
\hline & Count & In Percent & Count & In Percent \\
\hline 1. Anti-Imperialism + & 5 & 8.9 & 57 & 9.6 \\
\hline 2. Military/Defence + & 8 & 14.3 & 83 & 13.9 \\
\hline 3. Peace + & - & - & - & - \\
\hline 4. Intemationalism + & 5 & 8.9 & - & - \\
\hline 5. Pan-Islamism + & 29 & 51.8 & 58 & 9.7 \\
\hline 6. Foreign Policy & 9 & 16.1 & 79 & 13.2 \\
\hline 7. Global Powers & - & - & 146 & 24.5 \\
\hline 8. Kashmir \& Afghanistan & - & - & 174 & 29.2 \\
\hline Total & 56 & 100.0 & 597 & 100.0 \\
\hline
\end{tabular}

Source: Author's own database

\begin{tabular}{|l|l|l|l|l|}
\hline \multicolumn{5}{|c|}{ Table 4: Sub-Domain: Freedom and Democracy } \\
\hline \multirow{2}{*}{ Sub-Domain } & \multicolumn{2}{|l|}{ Manifesto } & \multicolumn{2}{l|}{ News Content } \\
\cline { 2 - 5 } & Count & In Percent & Count & In Percent \\
\hline 1. Freedom and Human Rights + & 20 & 51.3 & - & - \\
\hline 2. Freedom and Human Rights - & 6 & 15.4 & - & - \\
\hline 3. Democracy + & 12 & 30.8 & - & - \\
\hline 4. Constitutionalism + & 1 & 2.6 & - & - \\
\hline 5. Freedom and Democracy & - & - & 136 & 100.0 \\
\hline Total & 39 & 100.0 & 136 & 100.0 \\
\hline
\end{tabular}

Source: Author's own database

\begin{tabular}{|l|l|l|l|l|}
\hline \multicolumn{5}{|c|}{ Table 5: Sub-Domains: Political System } \\
\hline \multirow{2}{*}{ Sub-Domain } & \multicolumn{2}{|l|}{ Manifesto } & \multicolumn{2}{l|}{ News Content } \\
\cline { 2 - 6 } & Count & In Percent & Count & In Percent \\
\hline 1. Govt. \& Admin. Efficiency + & 57 & 57.0 & 83 & 7.6 \\
\hline 2. Govt. \& Admin. Efficiency - & 1 & 1.0 & - & - \\
\hline 3. Corruption \& Accountability & 32 & 32.0 & 89 & 8.2 \\
\hline $\begin{array}{l}\text { 4. Decentralization \& Prov. } \\
\text { Autonomy+ }\end{array}$ & 10 & 10.0 & 57 & 5.2 \\
\hline 5. Centralization + & & & & \\
\hline 6. Political Activism & - & - & - & - \\
\hline Total & - & - & 859 & 79.0 \\
\hline
\end{tabular}

Source: Author's own database 


\begin{tabular}{|l|l|l|l|l|}
\hline \multicolumn{5}{|c|}{ Table 6: Sub-Domains: Economy } \\
\hline & Manifesto & News Content \\
\hline & Count & In Percent & Count & In Percent \\
\hline 1. Free Enterprise + & 7 & 6.42 & - & - \\
\hline 2. Incentives + & 11 & 10.09 & - & - \\
\hline 3. Market Regulation + & 16 & 14.68 & - & - \\
\hline 4. Protectionism + & 2 & 1.83 & - & - \\
\hline 5. Economic Planning + & 5 & 4.59 & - & - \\
\hline 6. General Economic Goals & 10 & 9.17 & 111 & 100 \\
\hline 7. Technology and & 56 & 51.38 & - & - \\
\hline Infrastructure + & & & & \\
\hline 8. Nationalization + & - & - & - & - \\
\hline 9. Privatization + & 2 & 1.83 & - & - \\
\hline Total & 109 & 100 & 111 & 100 \\
\hline
\end{tabular}

Source: Author's own database

\begin{tabular}{|l|l|l|l|l|}
\hline \multicolumn{5}{|c|}{ Table 7: Sub-Domains: Welfare and Quality of Life } \\
\hline Sub-Domain & Manifesto & \multicolumn{1}{|l|}{ News Content } \\
\cline { 2 - 5 } & Count & Rel. Freq. & Count & Rel. Freq. \\
\hline 1. Social Justice + & 41 & 37.27 & 143 & 59.09 \\
\hline 2. Culture + & 12 & 10.91 & - & - \\
\hline 3. Welfare State Expansion + & 23 & 20.91 & 23 & 9.5 \\
\hline 4. Education Expansion + & 17 & 15.45 & - & - \\
\hline 5. Environmental Protection + & 17 & 15.45 & - & - \\
\hline 6. Social Activism & - & - & 76 & 31.4 \\
\hline Total & 110 & 100 & 242 & 100 \\
\hline
\end{tabular}

Source: Author's own database

\begin{tabular}{|l|l|l|l|l|}
\hline \multicolumn{5}{|c|}{ Table 8: Sub-Domains: Fabric of Society } \\
\hline \multirow{2}{*}{ Sub-Domain } & $\begin{array}{l}\text { Manifesto } \\
\text { Count }\end{array}$ & In Percent & Count & In Percent \\
\cline { 2 - 5 } & 14 & 23.33 & 34 & 25.19 \\
\hline 1. Social Harmony + & 39 & 65 & 81 & 60 \\
\hline 2. Law and Order + & 5 & 8.33 & 5 & 3.7 \\
\hline $\begin{array}{l}\text { 3. Anti-Feudalism \& Land } \\
\text { Reform + }\end{array}$ & & & & \\
\hline $\begin{array}{l}\text { 4. Anti-Capitalism + } \\
\text { 5. Ethno-politics }\end{array}$ & 2 & 3.33 & - & - \\
\hline Total & - & - & 15 & 11.11 \\
\hline
\end{tabular}

Source: Author's own database 


\begin{tabular}{|l|l|l|l|l|}
\hline \multicolumn{5}{|c|}{ Table 9: Sub-Domains: Social Groups } \\
\hline \multirow{2}{*}{ Sub-Domain } & \multicolumn{2}{|l|}{ Manifesto } & \multicolumn{2}{l|}{ News Content } \\
\cline { 2 - 5 } & Count & In Percent & Count & In Percent \\
\hline Labour Groups + & 38 & 31.9 & - & - \\
\hline Farmers + & 10 & 8.4 & - & - \\
\hline Under-privileged Minority Groups + & 22 & 18.5 & - & - \\
\hline Professional Groups + & 13 & 10.9 & - & - \\
\hline Gender + & 22 & 18.5 & 52 & 41.6 \\
\hline Youth + & 11 & 9.2 & - & - \\
\hline Other Social Groups + & 3 & 2.5 & 73 & 58.4 \\
\hline Total & 119 & 100 & 125 & 100 \\
\hline
\end{tabular}

Source: Author's own database

\begin{tabular}{|l|l|l|l|l|}
\hline \multicolumn{5}{|c|}{ Table 10: Sub-Domain: Islamic Ideology } \\
\hline \multirow{2}{*}{ Sub-Domain } & \multicolumn{2}{l|}{ Manifesto } & \multicolumn{2}{l|}{ News Content } \\
\cline { 2 - 6 } & Count & In Percent & Count & In Percent \\
\hline Islamic Shar'ia/Shar'ia Activism + & 8 & 21.05 & 211 & 72.26 \\
\hline Islamic Economy + & 7 & 18.42 & 13 & 4.45 \\
\hline Islamic Morality/Moral Activism + & 18 & 47.37 & 28 & 9.59 \\
\hline Islamisation (General) & 5 & 13.16 & - & - \\
\hline Jihad Activism & - & - & 40 & 13.7 \\
\hline Total & 38 & 100 & 292 & 100 \\
\hline
\end{tabular}

Source: Author's own database

Table 7 gives an idea of the overwhelming space given to the more abstract notion of social justice (37.27 per cent) in manifesto and 59.09 per cent in the news content), welfare state expansion is the minimum in the news content.

The Jamaat political discourse also has less emphasis on the pertinent issues of feudalism and land reforms in Pakistan (see Table 8). Mawdudi opposed the then Prime Minister, Liaqat Ali Khan's land reform in Punjab in the 1950s on the basis of protecting individual's private property rights in Islam (Nasr, 1996); for Binder, 1961, p. 211), such move by Mawdudi was an attempt to win the support of zamindars in the Punjab that might had positive influence on the Jamaat electoral outcomes (Binder, 1961). Similar is its stand on the issue of ethnicity. The overwhelming discourse on Islam as the basis of ethnicity and negation of race and territory as the basis of nationalism has a negative impact on the rights and conflicts among diverse ethnic groups. The relationship between religion and the ethnic question has two dimensions in a country like Pakistan, where the idea of nationalism is more a "concept" than an actual nationalism; the religious groups play a cementing/positive role in holding ethnicities together based on religious identity. However, this very role of religion subsides and undermines the issues of rights and identities of the various ethnicities. The Jamaat political history also reveals that over time, it has softened its position on the question of nationalism. It began with Mawdudi's "Islamo-transnationalism" before the partition of India, accepted national boundaries of Pakistan and India in 1947 (split the Jamaat along national lines) and showed a pragmatic concern by emphasizing on "Islamo-nationalism" (Roy, 2004). Some recent developments reveal that if opportunities arise, the Jamaat elite's response will be more in line with the political realities of Pakistan than Mawdudi's ideology. During MMA government in NWFP (2002-2007), the Jamaat central leader and key minister is reported to have issued statements in favour of the rights and share in resource distribution of his province.

The Jamaat political discourse also reveals an abstract conceptualisation of issues based on moral ideals and worldviews that enables it to escape concrete solutions of specific issues. For an ideological/revolutionary movement, in Gramscian analysis, "the discourse of political Islam seeks to unify individuals on the level of ideas and a common world perception, not necessarily by economic status or on the basis of material deprivation" (Butko, 2004). Islamists mention the "totality of human predicament" and the "totality of systemic failure" as the gross basis of miseries and problems. Whereas, such gross generalisations could be helpful in understanding the overall gravity of human miseries in Pakistan, 
they are less helpful in determining specific social and economic needs of society and the strategy to overcome them. Political conceptualization of needs must not only diagnose but also prognosticate the issues of the deprived class coupled with identifying symptoms and remedies in the given social context (Sen, 1999). Whereas, distribution of all idle public lands among the landless and seizing vast land illegally owned by the feudal class, as the Jamaat manifesto declares, would seem revolutionary and populist, in practice, it is the social and political context that would determine the pros and cons of such public actions.

Interaction with activists, shows a strong feeling of loss among ardent Jamaat members over active participation in practical politics (elections, protests, power struggle) and the negative impact it had on its ability to contribute to social and community development. Put simply, the Jamaat active pursuance of state power, in the eyes of its activists, has diverted attention from issues of social welfare and development to issues of power and agitation politics. Christopher Candland (2000) suggests in a comparative study of four religious associations including Jamaat that the "socially transformative power of religious institutions" is not only undermined by the "governments that attempt to use religious rhetoric to legitimate their policies" but also "religious political parties that rely upon the government to promote their strategies for social and political reform."

Apart from these views and discussions prevalent among the Jamaat formal and informal meetings, which are abstract and general in nature, the time trend in figures reveal that the media has captured a growing emphasis in the Jamaat politics on issues related to social groups, economy and social welfare (for more details see, Amin, 2010). In the recent past, interaction with a number of provincial leaders in the provinces of Punjab and NWFP also revealed that the awareness is growing within the Jamaat about re-organisation of its welfare organ (al-Khidmat Foundation) on professional lines. However, deeper analysis of figures reveals abrupt spikes in the post-2002 period, when the Jamaat as part of the MMA came in power in the province of NWFP, and thus most of the statements coded in this period were of the Jamaat provincial ministers (see for an elaborate analysis, Amin, 2010, Appendix B1-B8).

Recent scholarship discusses the role of religion (values, beliefs, practices, institutions, spiritual leaders, faith communities) in socio-political and economic development. Likewise, a number of researchers have studied Islamic welfare institutions run by the Islamic movements in the Middle East, mostly by Muslim Brotherhood and its sister organizations (Clark, 2004; Gunning, 2007). The Jl's welfare-activism in the social sector has rarely received any academic attention. In his study conducted in 1957 (p.65), renowned historian of the Pakistan movement, Khalid B. Sayeed cites Binder on the discipline and welfare activism of the Jamaat movement in the Pakistani province of Sindh at the time:

[t]heir offices seem to be well organised and their accounts well kept ... Their budgets are also fairly substantial, that of the Sindh provincial Jamaat being in the range of 100,000 Pakistan rupees in 1954. Most of this sum went for the supply of free medical care to refugees in Karachi area, for printing and paper, and for rent and salaries.

\section{Conclusion}

These opportunity spaces as product of neoliberal globalization thus transform neoliberalism not only into a system "but also as a conceptual and material ground for the emergence of the" Islamic movements in Pakistan and beyond. Thus neoliberal globalization as an opportunity space with a twofold universe for the Islamists: it provides them material (as well as discursive) conditions to imbibe in the realm of politics, civil society, preaching, media and welfare activism, and; it equips them to criticize, negotiate and reject aspects of neoliberal policy and discourse. Looking at the Jl's politics through the lens of News Content data provided in this paper further strengthens this argument that the Islamic movements' performative action in the neoliberal space is not uncritical but to use Euben's expression, the $\mathrm{Jl}$ sees in modernity "a crisis due to rupture with tradition, the dual rejection of theology and teleology inaugurated by Enlightenment rationalism and the subsequent diminishment of meaning in authority, morality and community..." (1999).

The data set helps to empiricize another aspect of the $\mathrm{Jl}$ politics that depicts clear departure from what an essentialist approach would normally portray. The Western media's depicts stereotyped images of Islamists, and the Islamists themselves popularize themes of radical transformation of state and society. This caricature of Islamism is best exemplified by one of Tibi's (2009) bold assertions: "[i]n the course of de-Westernization of the Islamic world, contemporary Islamists are leading Muslim people back into the Stone Age in the name of an Islamic epistemology" (ibid, p.79). From our data set, the Jamaat position can be interpreted in a couple of different ways: the diversity across issues and themes in the manifesto and news content, even without considering pragmatic political compromises reveals that the $\mathrm{Jl}$ does not desire a stone age and that the "demonic spirit" will not take over Pakistan if they accede to power. Largely, a capitalist model of development with an "Islamic trickle down" spawns from the data. At the same time, the data falls short of persuading us that the $\mathrm{Jl}$ seeks radical transformation of existing power relations, and prevailing class- 
based social and economic arrangements. Scholars have employed Antonio Gramsci's framework of hegemony-"a process of domination by consent and engineered conformism"-to explain and understand Islamists' tide everywhere (Brohi, 2006; Tugal, 2009). Brohi takes the example of MMA (of which Jl was a part in 2002 elections) that according to her is not "counter-hegemonic", rather it "sides with the exploitative classes and strengthen capitalism ... not challenging class divisioning in society" (ibid, pp.12-13). Ample theoretical and empirical evidence supports the claim that the $\mathrm{JI}$ transformation has strategic and political connotations. Within the $\mathrm{Jl}$, however, an ideological-conceptual transformation remained a distant dream. One reason might be the perpetual secession, disdain for and expulsion of scholars and intellectuals from the $\mathrm{JI}$ at various times. As one of the Jl's influential elite told me in an interview that the Jl's current politics and Mawdudi's doctrines are not synonymous. In real practice, the $\mathrm{Jl}$ through its perpetual interaction with the existing capitalist system has left the Islamist ideology behind. It is now common observation that political Islamists negotiate their principle positions according to opportunity spaces. Over time, as new avenues of engagement are opened up for them, they gradually tend to moderate their doctrinaire positions (See for example, on the transformation of AK party in Turkey, Cavdar, 2006). The Jl is not an exception to the general trend.

Finally, the data set and the analysis in this paper do not answer to a set of critical questions pertaining to the Jl's bad performance in electoral politics and its failure to appeal to the popular will. More research is needed to further probe why the $\mathrm{Jl}$ has largely failed in its electoral strategies, more in a comparative fashion with parties such as Justice and Development Party in Turkey as well as in Tunisia (some research studies analyze the "exportability" of Turkish Islamist model to other Muslim countries, mostly the Middle East. See for example, Taspinar, 2003).

\section{Acknowledgment}

This work was supported by the DRS COFUND Fellowship Program of Freie Universität Berlin and the European Commission, project reference number: PCOFUND-GA-2010-267228. The author is also much indebted to the Berlin Graduate School Muslim Cultures \& Societies (BGSMCS) for hosting me during my research stay, March 2013 - July 2014.

\section{References}

Ahmad, M. (1991). The Jamaat-e-Islami and the Tablighi Jamaat of South Asia. In M. E. Marty \& R. S. Appleby (Ed.), Fundamentalisms Observed, Chicago: The University of Chicago Press (pp.457-530).

Ahmad, I. (2009). Islamism and Democracy in India: the transofmation of Jamaat-e-Islami, Princeton University Press.

Akhtar, R.S. (2000). Media, Religion and Politics in Pakistan, USA: Oxford University Press (p. XXV).

Amin, H. (2010, April). From Islamism to post-Islamism: a study of a new intellectual discourse on Islam and modernity in Pakistan. Unpublished doctoral dissertation, ISS, Erasmus University, Rotterdam.

Anjum, O. (2007). Islam as a Discursive Tradition: Talal Asad and his interlocutors. Comparative Studies of South Asia, Africa and the Middle East, 27 (3) 656-672.

Arendt, H. (1953). Ideology and Terror. Can be accessed at: http://mrkaminski.weebly.com/uploads/2/3 11/6/23161936/ideology_and_terror_1953--hannah_arendt.pdf

Ashar, U. (Ed.). (2004). Pakistan ki Siyasi Jamaatain (Political Parties of Pakistan). Lahore: Sang-e-Meel Publications (pp. 677-96).

Azmi, A.A. (2002) Ahya-e-Millat awr Deeni Jamaatain (Revival of Muslim Ummah and the Religious Organizations), Lahore: Dar-alTazkeer.

Binder, L. (1961). Religion and Politics in Pakistan. Berkeley: University of California Press.

Brohi, N. (2006). The MMA Offensive: Three Years in Power 2003-2005, Islamabad: Action Aid International Pakistan (pp.1-2).

Budge, I. (2001). Validating the Manifesto Research Group Approach: Theoretical Assumptions and Empirical Confirmations. In M. Laver (Ed.), The Policy Positions of Political Actors, London \& New York: Routledge (pp. 50-65).

Butko, T.J. (2004). Revelation or Revolution: a Gramscian approach to the rise of political Islam. British Journal of Middle Eastern Studies, 31(1), 41-62.

Candland, C. (2000). Faith as social capital: Religion and community development in Southern Asia. Policy Sciences, 33(3), 371.

Cavdar, G. (2006). Islamist New Thinking in Turkey: A Model for Political Learning? Political Science Quarterly, 121(3), 477-497.

Clark, A. J. (2004). Islam, Charity, and Activism: middle-class networks and social welfare in Egypt, Jordan, and Yemen. Indiana University Press.

Court, A. Hannah Arendt's Theory of Totalitarianism. Rozenberg Quarterly, posted 23 May 2012. Can be accesses at: http://rozenbergquarterly.com/hannah-arendts-theory-of-totalitarianism-part-two/

Esposito, J. (1999). The Islamic threat myth or reality? New York: Oxford University Press (p. 8).

Esposito, J., \& Voll, J. (1996). Islam and democracy, New York: Oxford University Press (p.5).

Euben, L. R. (1999). Mapping Modernities, 'Islamic' and 'Western'. In F. R. Dallmayr (Ed.) Border Crossings: Toward a Comparative Political Theory, Lanham, MD: Lexington Books (p.19). 
Euben, L. R. (1999). Enemy in the mirror: Islamic fundamentalism and the limits of modern rationalism: a work of comparative political theory. Princeton University Press.

Gunning, J. (2007). Hamas in Politics: Democracy, Religion, Violence. London: Hurst and Company.

Haar, T., \& Ellis, S. (2006). The Role of Religion in Development: Towards a New Relationship between the European Union and Africa. European Journal Of Development Research, 18(3), 351.

Kotz, D.M. (2002). Globalization and Neoliberalism. Rethinking Marxism, 12 (3) 64-79. Can be accessed at: http://people.umass.edu/dmkotz/Glob_and_NL_02.pdf

Kramer, M. (2003). Coming to Terms: fundamentalists or Islamists? Middle East Quarterly, 10, 65-78.

Laver, M. (Ed.). (2001) Estimating the Policy Positions of Political Actors, London \& New York: Routledge (pp. 3-9).

Laver, M., et al. (2003). Estimating Policy Positions from Political Texts Using Words as Data. American Political Science Review, 97 (2), 311-331.

Lewis, B. (2002). What went wrong? Atlantic Monthly, 289 (1) 43-45.

Mayotte, J.A. (1998). Religion and global affairs: the role of religion in development. SAIS Review 18(2) 65-69.

Moten, A. (2002). Revolution to Revolution: Jamaat-e-Islami in the politics of Pakistan, Kualalampur: Islamic Book Trust.

Nasr, V. R. (1994). The Vanguard of the Islamic Revolution: the Jamaat-i Islami of Pakistan, University of California Press.

Nasr, V.R. () Mawdudi and the Making of Islamic Revivalism. NY: Oxford University Press (pp. 74-76).

Nayab, D. (2011). Estimating the Middle Class in Pakistan. The Pakistan Development Review, Islamabad: Pakistan Institute of Development Economics, 50 (1) 1-28.

Report ISPS (2010). Private Sector Education in Pakistan: mapping and musing. Islamabad: Institute of Social and Policy Studies Islamabad. Available on the net at: <http://i-saps.org/Publications/Private\%20Sector\%20Education\%20Report-I-SAPS.pdf>

Roy, O. (2004). Globalized Islam: the search for a new Ummah. New York: Columbia University Press (pp. 62-67).

Sayeed, K.B. (1957). The Jamaat-e-Islami Movement in Pakistan. Pacific Affairs 30 (1) 59-68.

Sen, A. (1999). Development as freedom, Oxford University Press.

Taspinar, O. (2003). An Uneven Fit? The "Turkish Model" and the Arab World. Washington DC: The Saban Center for the Middle East Policy at the Brookings Institute.

Tibi, B. (2012). Islamism and Islam. New Haven \& London, Yale University Press.

Tibi, B. (2009). Islam's Predicament with Modernity. New York: Routledge.

Tugal, C. (2009). Passive Revolution: Absorbing the Islamic Challenge to Capitalism. California: Stanford Univ Press.

Volkens, A. (2005). Manifesto Data Set MDS 2005 Data Handbook [electronic version].

Yavuz, H. (2003). Islamic political identity in Turkey. USA: Oxford University Press (p. 24).

Zaidi, S.A. (2005). Issues in Pakistan's Economy. Karachi: Oxford University Press. 